\title{
Response of soil microbial community to afforestation with pure and mixed specie
}

Gunina, Anna; Smith, Andrew; Godbold, Douglas; Jones, David; Kuzyakov, Yakov

\section{Plant and Soil}

DOI:

$10.1007 / \mathrm{s} 11104-016-3073-0$

Published: 01/03/2017

Peer reviewed version

Cyswllt i'r cyhoeddiad / Link to publication

Dyfyniad o'r fersiwn a gyhoeddwyd / Citation for published version (APA):

Gunina, A., Smith, A., Godbold, D., Jones, D., \& Kuzyakov, Y. (2017). Response of soil microbial community to afforestation with pure and mixed specie. Plant and Soil, 412(1-2), 357-368. https://doi.org/10.1007/s11104-016-3073-0

\footnotetext{
Hawliau Cyffredinol / General rights

Copyright and moral rights for the publications made accessible in the public portal are retained by the authors and/or other copyright owners and it is a condition of accessing publications that users recognise and abide by the legal requirements associated with these rights.

- Users may download and print one copy of any publication from the public portal for the purpose of private study or research.

- You may not further distribute the material or use it for any profit-making activity or commercial gain

- You may freely distribute the URL identifying the publication in the public portal?
}

Take down policy

If you believe that this document breaches copyright please contact us providing details, and we will remove access to the work immediately and investigate your claim. 
3 Anna Gunina ${ }^{\mathrm{a}, \mathrm{b}}$, Andrew R. Smith ${ }^{\mathrm{a}}$, Douglas L. Godbold ${ }^{\mathrm{c}}$, Davey L. Jones ${ }^{\mathrm{a}}$ and Yakov Kuzyakov ${ }^{\mathrm{b}, \mathrm{d}}$ 4

${ }^{\text {a }}$ School of Environment, Natural Resources and Geography, Bangor University, Bangor, Gwynedd, $6 \quad$ LL57 2UW, UK;

7 b Department of Agricultural Soil Science, Georg August University of Göttingen, Göttingen, $8 \quad 37077$, Germany;

9 c Institute for Forest Ecology, Universität für Bodenkultur, BOKU, Peter-Jordan-Straße 82, 1190

10 Vienna, Austria;

$11{ }^{\mathrm{d}}$ Department of Soil Science of Temperate Ecosystems, Georg August University of Göttingen, 12 Göttingen, 37077, Germany

13

14

15

16

17

18 Corresponding Author:

19 Anna Gunina

20

21

22

23

24

25

email: guninaann@gmail.com

Georg-August-University of Göttingen

Buesgenweg 2

37077 Göttingen

Tel: 0551/39-20502

Tel.: +49 0157/85566093

Department of Agricultural Soil Science 


\section{Abstract}

Objectives

Afforestation changes soil chemical properties over several decades. In contrast, microbial community structure can be shifted within the first decade and so, the direct effects of tree species can be revealed. The aim of this study was to determine the alteration of soil microbial community composition 10 years after afforestation by trees with contrasting functional traits.

\section{Methods}

The study was conducted at the BangorDIVERSE temperate forest experiment. Soil samples were collected under single, two and three species mixtures of alder and birch, beech and oak - early and secondary successional species, respectively, and contiguous agricultural field. Soil was analysed for total carbon $(\mathrm{C})$ and nitrogen $(\mathrm{N})$ contents, and microbial community structure (phospholipid fatty acids (PLFAs) analysis).

\section{Results and conclusions}

The total PLFAs content (370-640 $\mathrm{nmol} \mathrm{g}^{-1}$ soil) in forest plots increased for 30 to $110 \%$ compared to the agricultural soil $\left(290 \mathrm{nmol} \mathrm{g}^{-1}\right.$ soil). In contrast, soil $\mathrm{C}, \mathrm{N}$ and $\mathrm{C} / \mathrm{N}$ ratios were altered over 10 years much less - increased only up to $20 \%$ or even decreased (for beech forest).

Afforestation increased bacterial PLFAs by $20-120 \%$, whereas it had stronger impact on the development of fungal communities (increased by $50-200 \%$ ). These effects were proved for all forests, but were more pronounced under the monocultures compared to mixtures. This indicates that species identity has a stronger effect than species diversity. Principal component analysis of PLFAs revealed that under mono and three species mixtures similar microbial communities were formed. In contrast, gram-positive PLFAs and actinomycete PLFAs contributed mainly to differentiation of two species mixtures from other forests. Thus, at the early afforestation stage: i) soil biological properties are altered more than chemical, and ii) tree species identity affects more than species amount on both processes. 
53 Keywords: woodland, plant microbial interactions, microbial biomarkers, land use change, forest 54 composition, ammonium and nitrate, soil solution, tree identity.

55

56 


\section{Introduction}

Forests in the European Union cover more than 180 million ha representing $41 \%$ of the total land area. In response to a range of European policies (e.g. EU Biodiversity Strategy, EU Forest Strategy) afforestation area has increased by 17 million ha in the last 25 years and this trend is expected to continue for the foreseeable future (EEA, 2015). Both pure and mixed species forests are used for afforestation of former arable and grassland soils, however, there is still a lack of information on the effects of various tree species on maximising soil function (e.g. enhancing carbon $(\mathrm{C})$ and nitrogen $(\mathrm{N})$ storage, promoting nutrient cycling and water storage), and especially on the changes in soil microbial communities. This fundamental knowledge would be useful to make informed management decisions to maximise both above and below-ground diversity and to promote sustainable landscape functioning.

Forest soil properties are altered by the processes of tree establishment, growth and mortality. Soil $\mathrm{C}$ and $\mathrm{N}$ stocks generally increase with forest age and achieve their maximum accumulation rates during the exponential tree growth phase (DeLuca and Boisvenue 2012), and gradually decline in late successional forest stages. Approximately 30-50 years after afforestation, soil $\mathrm{C}$ and $\mathrm{N}$ stocks begin to stabilize (Fu et al. 2015; Kalinina et al. 2011). The quality of leaf litter also changes with forest age (e.g. decrease in leaf nutrient content, increased in $\mathrm{C} / \mathrm{N}$ and lignin/ $\mathrm{N}$ ratios), which directly affects litter decomposition and soil nutrient supply (Trap et al. 2013). A well-known effect of afforestation is soil acidification (Berthrong et al. 2009) due to changes in soil base saturation, litter chemistry, rhizodeposition and absence of liming ( $\mathrm{Fu}$ et al. 2015). The reported $\mathrm{pH}$ decrease for 27 year-old broadleaf forests was around 0.95 units (Fu et al. 2015), while it is estimated that between $80-100$ years of forest development is required to obtain $\mathrm{pH}$ values close to those found in native forests (Ritter et al. 2003). Overall, this suggests that soil acidity and $\mathrm{C}$ and $\mathrm{N}$ stocks change very slowly during afforestation.

Concurrent with changes in soil chemistry, the biomass, quality composition and diversity of soil microbial communities can also be expected to shift following trees establishment (Grayston et 
al. 1997b; Macdonald et al. 2009). Afforestation induce a rapid increase in microbial biomass with changes apparent within one year of tree planting (van der Wal et al. 2006). Afforestation typically stimulates the development of fungal communities (Jangid et al. 2011; Buckley and Schmidt 2003), whereas bacteria appear to be less sensitive to land use changes (Klein et al. 1995). In addition, the diversity and relative abundance of individual fungal and bacterial species have been shown to increase after afforestation. For example, Acidobacteria appeared to dominate under birch while Firmicutes and Proteobacteria were more dominant under young pine forests (Nazaries et al. 2015). Thus, microbial communities might serve as a primary indicator of ecosystems recovery as their changes occur more rapidly than for soil chemical properties.

Forests affect the composition of microbial communities not only directly (Fu et al. 2015), Mann and Tolbert 2000) depending on the forest type, biodiversity, and land use history (Yannikos et al. 2014). The time range needed for microbial communities to evolve to those typical of native forests is estimated to be 30 - 50 years (Jangid et al. 2011; Buckley and Schmidt 2003; van der Wal et al. 2006) and is affected by the rate at which soil properties change (van der Wal et al. 2006). Generally, the composition of microbial communities formed under broadleaf forests is radically different from those formed under coniferous species ( $\mathrm{Li}$ et al.; Cong et al. 2015). These differences can be ascribed mainly due to variations in leaf litter chemistry, changes in mycorrhizal communities and colonization. Comparison of soils formed under broadleaf forest has also revealed that tree species like beech promote development of microbial communities different from those developed under ash, lime and hornbeam forests, mainly due to low $\mathrm{C} / \mathrm{N}$ ratio of beech litter, presence of microbial activity inhibitors in root exudates and more rapid decreases in soil $\mathrm{pH}$ (Scheibe et al. 2015). Composition of forest was also reported to affect microbial community structure, which was found for the beech grown in mono- and mixed forests (Thoms and Gleixner 2013). However, in addition to forest community composition, variations in functional traits of trees should be accounted for due to their strong potential effects on the formation and shaping of soil 
microbial communities ( $\mathrm{Fu}$ et al. 2015). Thus, due to a variety of complex interacting factors, it is

110 difficult to disentangle the direct effects of forest tree community composition from the effect of

111 soil properties on microbial community dynamics, especially under mature forests, where soil

112 chemical properties may have already been changed. Further, it is difficult to distinguish between

113 tree identity and forest tree community composition effects, because functional traits of single tree

114 species can be masked or reduced in forest mixtures. Thus, only in experiments where both single

115 species and mixtures of trees are studied simultaneously in the early afforestation stage can

116 conclusions about the effect of tree identity and forest composition on the formation of soil

117 microbial communities be made.

118 The objective of this study was to evaluate the effects of forest tree community composition 119 on soil microbial community structure at the early forest development stage (10 years after 120 afforestation). It was hypothesized that independent of forest type, i) microbial community structure 121 will change more strongly than soil physico-chemical properties and ii) fungal biomass will 122 increase faster than bacterial biomass; iii) monoculture forests will promote strong and more 123 specific changes in content of particular microbial groups, whereas in species mixtures these 124 responses will be dampened.

\section{Materials and methods}

\section{$127 \quad$ Study site and soil sampling}

128 Soils were obtained from the BangorDIVERSE forest experiment located at the Henfaes

129 Research Centre, North Wales, UK $\left(53^{\circ} 14^{\prime} \mathrm{N}, 4^{\circ} 01^{\prime} \mathrm{W}\right)$. Climate was characterized as hyperoceanic,

130 with mean annual precipitation of $1034 \mathrm{~mm}$ and mean annual temperature of $11.5^{\circ} \mathrm{C}$ (Campbell

131 Scientific Ltd, Shepshed, UK). The site was set up in 2004 with a total area of 2.36 ha. Soils are

132 classified as Eutric Fluvic Cambisols (WRB 2006) (Fluventic Dystrochrept, USDA system) and

133 have fine loamy texture (Smith A. et al. 2013). Each type of forests, namely: single species or two

134 and three species mixtures of European alder (Alnus glutinosa L.), Silver birch (Betula pendula 
135 Roth), European beech (Fagus sylvatica, L.), and English oak (Quercus robur L.) were planted in 136 four independent field replication, with a size replications were: 62,121 and $196 \mathrm{~m}^{2}$ for the single,

137 two and three species forests, respectively. Forests were formed by tree species with contrasting 138 functional traits: early primary and late successional stages species, $\mathrm{N}$-fixing and non $\mathrm{N}$-fixing, 139 producing low and high litter quality. Monoculture species plots of alder, birch, beech and oak, two 140 species mixtures of alder+beech, alder+oak, birch+beech, birch+oak, three species mixtures of 141 alder+birch+beech, alder+birch+oak were used for the present experiment. The understory was 142 formed mainly by grass, goose grass, nettle, bramble and dock. Only the plots taken for that study 143 are mentioned, and for a full description of the experimental design see Ahmed et al. (2016). The 144 main properties of the plant communities are presented in Table 1. Contiguous agricultural field 145 (established before the BangorDIVERSE experiment), was chosen as a comparative soil due to its 146 same historical land use and soil type. The latest cultivation species at the agricultural field was 147 oilseed rape (Brassica napus) had been cultivated there following the addition of $\mathrm{K}_{2} \mathrm{O}\left(20 \mathrm{~kg} \mathrm{ha}^{-1}\right)$ 148 and $\mathrm{N}\left(60 \mathrm{~kg} \mathrm{ha}^{-1}\right)$. Soil samples were collected from the $0-10 \mathrm{~cm}$ depth from each field replication, 149 and each sample was consisted of three independent soil cores. Each sample was divided into three 150 parts: one was stored at $5{ }^{\circ} \mathrm{C}$ and used for extraction of soil solution, the second was dried at $105{ }^{\circ} \mathrm{C}$ 151 and used for total $\mathrm{C}$ and $\mathrm{N}$ analysis (Supplementary Table 2), and the third was stored at $-20{ }^{\circ} \mathrm{C}$ and 152 used for phospholipid fatty acid (PLFA) analysis.

\section{Analysis of soil quality indicators}

Soil samples were dried at $105{ }^{\circ} \mathrm{C}$ and ball milled before $\mathrm{C}$ and $\mathrm{N}$ analysis by dry combustion (Elemental analyzer, Vario EL III, Jena, Germany). Soil C and N stocks were

157 calculated based on the $\mathrm{C}$ and $\mathrm{N}$ contents and soil densities (it varied between $0.7-1 \mathrm{~g} \mathrm{~cm}^{-3}$ for forest 158 soils and was $1.2 \mathrm{~g} \mathrm{~cm}^{-3}$ for the agricultural soil). Soil solution was obtained by the centrifugal 159 drainage procedure described in Glanville et al. (2012) using $100 \mathrm{~g}$ of fresh soil samples. The concentration of $\mathrm{NH}_{4}{ }^{+}$in soil solution was determined colorimetrically using the sodium- 
nitroprusside, while $\mathrm{NO}_{3}^{-}$was determined colorimetrically using the $\mathrm{VCl}_{3}$ (both procedures described in Mulvaney (1996)).

\section{Phospholipid fatty acids analysis}

Phospholipid fatty acids (PLFAs) were extracted from the soil samples according to Frostegard (1991). Briefly, $4.5 \mathrm{~g}$ of fresh soil were placed into $50 \mathrm{ml}$ centrifuge tubes, $25 \mu 1$ of internal standard one added ( $1 \mu \mathrm{g} \mu \mathrm{l}^{-1}, 19: 0$ phospholipid) and lipids extracted twice (18 and $6 \mathrm{ml}$, respectively) by one phase mixture of chloroform, methanol and citric acid $(0.15 \mathrm{M}, \mathrm{pH} 4.0)$ in the ratio 1:2:0.8 (v/v/v). Extracted lipids were applied to the silica column and neutral-, glyco- and phospholipids were sequentially eluted from the column by chloroform $(5 \mathrm{ml})$, acetone $(20 \mathrm{ml})$ and methanol $(20 \mathrm{ml})$, respectively. Collected phospholipids were saponified (0.3 $\mathrm{M}$ solution of $\mathrm{BF}_{3}$ in methanol), obtained fatty acids were methylated (1 $\mathrm{M}$ solution of $\mathrm{NaOH}$ in methanol) and extracted in hexane. Finally, the samples were dried under a stream of $\mathrm{N}_{2}$ and redissolved in toluene (185 $\left.\mu \mathrm{l}\right)$ with addition of internal standard two (15 $\mu 1$ of 13:0 fatty acid methyl ester, $\left.1 \mu \mathrm{g} \mu \mathrm{l}^{-1}\right)$. HP-1 methylpolysiloxane coupled with a 30 m HP-5 (5\% phenyl)-methylpolysiloxane column (both

177 with an internal diameter of $0.25 \mathrm{~mm}$ and a film thickness of $0.25 \mu \mathrm{m})$ ), He flow of $2 \mathrm{ml} \mathrm{min}^{-1}$, and 178 injection volume of $1 \mu 1$. The temperature program of GC-MS was set up to $80{ }^{\circ} \mathrm{C}$ and then ramped 179 to $164{ }^{\circ} \mathrm{C}$ at $10{ }^{\circ} \mathrm{C} \mathrm{min}-1$, then to $230{ }^{\circ} \mathrm{C}$ at $0.7{ }^{\circ} \mathrm{C} \mathrm{min}{ }^{-1}$ and finally to $300{ }^{\circ} \mathrm{C}$ at $10^{\circ} \mathrm{C} \mathrm{min}^{-1}$. The 180 quantity of PLFAs was calculated based on the 29 external standards (Gunina et al. 2014), which 181 were prepared in 6 concentrations (Apostel et al. 2013). Final content of single PLFAs was 182 presented as molar percentages $(\mathrm{mol} \%)$ and total content was presented as $\mathrm{nmol} \mathrm{g}^{-1}$ soil. 183 Classification of PLFAs was done according to existing data on their presence in various groups of

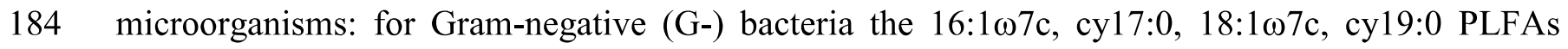
were used (Leckie 2005; Lewandowski et al. 2015), for Gram-positive bacteria (G+) i15:0, a15:0, 186 i16:0, i17:0 PLFAs were used (Leckie 2005; Lewandowski et al. 2015), for actinomycetes (Ac) 
10Me16:0 and 10Me18:0 were used (Lewandowski et al. 2015; Leckie 2005), for fungi

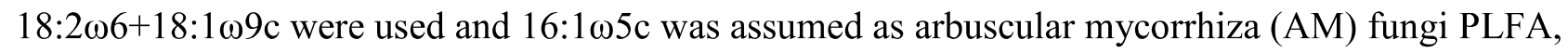

189 but with caution due to its high possible input from G- bacterial biomass (Leckie 2005;

190 Lewandowski et al. 2015).

\section{Statistical analysis}

To compare the effect of forest development on soil chemical properties and on microbial biomarkers contents, changes of all parameters were calculated relatively to agricultural soil. Changes of the soil chemical properties (except $\mathrm{pH}$ ) relatively to the agricultural soil have been calculated as:

$$
\frac{C p_{f}-C p_{a g r}}{C p_{a g r}}
$$

where, $C p_{f}$ and $C p_{a g r}$ are the values of chemical properties in the forest and agricultural soils, respectively. For $\mathrm{pH}$ absolute changes were calculated by subtracting $\mathrm{pH}$ of agricultural soil from $\mathrm{pH}$ of forest soils.

The increase of PLFAs of distinct groups relatively to agricultural plot was calculated as:

202

$$
\frac{P L F A_{f}-P L F A_{a g r}}{P L F A_{a g r}}
$$

where, PLFA $_{\mathrm{f}}$ and PLFA agr are the contents of PLFAs of specific microbial groups in forest and agricultural soils (nmol g ${ }^{-1}$ soil), respectively. Data were checked for the normal distribution and homogeneity was tested by Levene's test. Calculated values were tested with one-way ANOVA and significant differences were obtained with Notched Box Plots.

Principal component analysis (PCA) of mol\% of individual PLFAs was done to elucidate major variation pattern. The scores of the first two components from the PCA were used to separate the soils formed under various forests. Linear regression of PLFAs factor scores and soil properties $210\left(\mathrm{pH}\right.$, total $\mathrm{C}$ and $\mathrm{N}$, concentration of $\mathrm{NH}_{4}{ }^{+}$and $\left.\mathrm{NO}_{3}{ }^{-}\right)$was done to conclude about the correlation of 
PLFAs composition with environmental factors depending on the forest type. Statistical analyses

212 were done in Statistica 12.0 and Microsoft Excel 2010.

\section{Results}

215 Afforestation effects on soil properties

216 Afforestation had weak effect on the $\mathrm{C}$ content: the maximal changes of soil $\mathrm{C}$ content was 217 ca. $20 \%$ relative to the agricultural soil (Fig. 1), and was maximal for the birch, alder+oak and 218 birch+beech plots. However, $\mathrm{C}$ stocks in the upper $10 \mathrm{~cm}$ under pure oak, beech, two species 219 mixtures with oak and three species mixtures were lower compared to the agricultural soil 220 (Supplementary Table 2), mainly because of the low bulk density of the forest soils (it varied 221 between $0.7-1 \mathrm{~g} \mathrm{~cm}^{-3}$ for forest soils and was $1.2 \mathrm{~g} \mathrm{~cm}^{-3}$ for the agricultural soil).

222 The effect of forest development on soil N content (Fig. 1) followed the same tendency as 223 on $\mathrm{C}$ content, despite the contrasting $\mathrm{N}$ content of the various forest litters (Table 1). In general, 224 changes of total $\mathrm{N}$ content in the forest soils were similar and ranged within $\pm 15 \%$. The organic 225 matter quality, characterized by $\mathrm{C} / \mathrm{N}$ ratio, was the most strongly affected for the pure birch, 226 birch+beech plots and alder+beech, where it had the highest increase relative to agricultural soil 227 (Fig. 1).

10 years of afforestation decreased soil acidity by 1.0-1.2 units compared to the agricultural plot (Fig. 1).

The $\mathrm{NO}_{3}{ }^{-}$concentrations in soil solution decreased for the birch, beech and two forest 231 mixtures with birch compare to the agricultural soil (Fig. 1). In contrast, $\mathrm{NH}_{4}{ }^{+}$did not differ in the 232 agricultural and forest soils (Fig. 1).

\section{Afforestation effects on total PLFAs content}

Maximal contents of total microbial PLFAs were observed for the oak, birch and alder forest 
compare to pure beech forest, whereas no differences were found between the two and three species mixtures. In the case of the two species mixtures where beech was present, total PLFA content increased relative to the beech monocultures, whereas, the opposite trends were observed for the pure oak forest and two species mixtures containing oak.

\section{Afforestation effects on the content of specific microbial biomarkers}

Afforestation increased fungal PLFAs content the most compared to other biomarkers, and were $50-200 \%$ higher in the forest soils compared to the agricultural (Fig. 3). The maximal increase was found for the soils under birch, oak, alder and birch+beech. The two and three species forests increased their fungal biomarker content by $50-100 \%$.

Bacterial biomarkers increased in forest soils (except beech, three species mixture with 248 beech and birch+oak) by 20 to $110 \%$ compared to the arable soil but without differences in the $\mathrm{G}+$ 249 and G- groups (Fig. 3). The content of G+ bacterial PLFAs were low for the monocultural beech 250 forest, but increased for the two species mixtures with beech. In contrast, the content of G+ PLFAs 251 were higher for the monocultural oak forests, than for the birch + oak mixed forest. biomarker) increased by 30-120\% (Fig. 3) and the increase was higher under the birch and oak 254 treatments than for any other soils. Both beech alone and in three species mixtures forests 255 containing beech resulted in a decline of 16:1®5 PLFAs relative to the agricultural soil. The content 256 of actinomycete PLFAs followed the same trend as 16:1ø5 PLFA, however, the highest increase 257 was found for the alder+beech plot.

PCA analysis of the PLFA data revealed that the first two PCA components explained 38 259 and $21 \%$ of the PLFA variation, respectively (Fig. 4). The first PCA component reflects differences 260 in soil $\mathrm{pH}\left(r^{2}=0.32\right.$; linear regression of scores for PC1 vs. soil $\left.\mathrm{pH}\right)$ and was correlated with 261 saturated/monounsaturated ratio $\left(r^{2}=0.45\right)$. The second PCA component was correlated with 262 fungal/bacterial ratio $\left(r^{2}=0.69\right)$ and also can be explained by soil $\mathrm{pH}\left(r^{2}=0.73\right)$. Both PC1 and PC2 
were correlated with the cyclo/precursor ratio (for PC1 $r^{2}=0.38$ and for $\mathrm{PC} 2 r^{2}=0.40$ ). Both ratios are presented in the Table 2.

According to the PCA results the agricultural soil was separated from the mono- and three species mixture forests along the PC1 and PC2 and only along PC2 from the two species mixtures forests. Bacterial biomarkers $(18: 1 \omega 7$, cy17:0, i15:0 and i17:0) contributed to the separation of forest soils from the agricultural plot along PC1, whereas fungal $(18: 2 \omega 6,9$ and 18:1 $\omega 9)$ and Gbiomarkers (cy19:0) were responsible for the separation along PC2 (Fig. 4, top). The agricultural

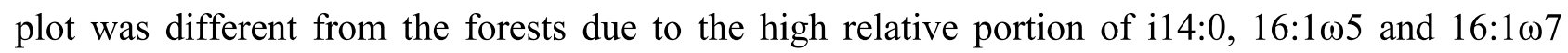
PLFAs in total PLFAs content, which were 1.1-1.5 times higher in the agricultural relative to the forest soils (Supplementary table 1).

Single and three species mixtures forest soils were separated from the two species mixture forests along PC1 (Fig. 4, top). Based on the loading values (Fig. 4, bottom), Ac (10Me16:0 and

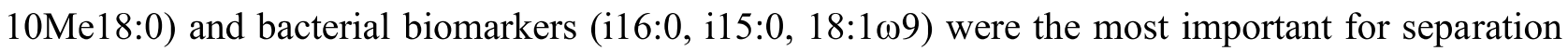
the two species mixtures from single and three species mixtures forests. In contrast, mono- and three species mixtures were only weakly separated on PC 2, and no separation along PC1 was 278 found.

\section{Discussion}

\section{Afforestation effects on soil chemical properties}

Afforestation typically results in an improvement in soil quality and an increase in total C and N content (Laganière et al. 2012; Kurganova et al. 2015; Paul et al. 2002). Soil C content increased by $20 \%$ (for some plots) in the top $10 \mathrm{~cm}$ when compared to the adjacent agricultural on which the forest was established (Fig. 1). Such small changes are related to: i) prolonged effects of former land use management on the total soil $\mathrm{C}$ content within the first 10 years after afforestation (Paul et al. 2002), ii) occurrence of opposing processes during afforestation: a) large inputs of tree 
this new substrate, and at the same time b) intensive decomposition of the intrinsic agriculturederived SOC due to the increased activity and content of microbial biomass. As a result, C mineralization can exceed accumulation in the surface soil layer during early afforestation.

Total soil $\mathrm{N}$ content in the forest soils were similar to the agricultural plot, except for pure beech stand, where it decreased by $15 \%$ and alder+oak plot where $\mathrm{N}$ content increased by $15 \%$ (Fig. 1). N stocks were lower in all forest soils compared to the agricultural soil (Supplementary Table 2), mainly because of decrease of soil density. Afforestation has a strong effect on $\mathrm{N}$ dynamics in soils and induces changes in $\mathrm{N}$ mineralization, ammonification and nitrification rates (Li et al. 2014). Moreover, young trees have a high demand for $\mathrm{N}$, resulting in a redistribution from soils into tree biomass (Uri et al. 2003). The dominating form of the $\mathrm{N}$ in soil solution in afforested soils was nitrate, although this was lower than in the agricultural soil (Fig. 1, Supplementary Table 2). In contrast, no strong effect of afforestation on $\mathrm{NH}_{4}{ }^{+}$concentration was found. The decrease of $\mathrm{NO}_{3}{ }^{-}$ concentrations is common for forest soils is a consequence of lower $\mathrm{pH}$, higher $\mathrm{C}$ input, absence of fertilization and intensive uptake of $\mathrm{N}$ by plants, all of which reduce nitrification rates ( $\mathrm{Li}$ et al. 2014).

In agreement with previous afforestation studies (Berthrong et al. 2009; Kalinina et al. 2011), a decrease in soil $\mathrm{pH}$ was observed in all forest plots. We ascribe this to, i) changes in the amount of rhizodeposition, which is around $50 \%$ of total assimilated $\mathrm{C}$ belowground for trees vs. $10-40 \%$ for annual plants (Grayston et al. 1997a), ii) changes in root and ectomycorrhizal exudate quality, which often contain a high variety and amount of organic acids (Grayston et al. 1997a), iii) an increased uptake of cations by trees (Jobbágy and Jackson 2003), iv) shifts in litter quality, and v) an absence of liming. We conclude therefore that while early afforestation does not promote strong changes in some soil chemical properties (e.g. total $\mathrm{C}$ and $\mathrm{N}$ content, $\mathrm{C} / \mathrm{N}$ ratio) it can promote large changes in more dynamic soil quality indicators (e.g. $\mathrm{pH}$ and available $\mathrm{N}$ form). 
Development of forests usually increases total PLFAs content (Jangid et al. 2011) and for

317 our study it was true mostly for the soils under the monoculture forests formed by alder, birch and 318 oak and also in two species forest mixtures with beech (Fig. 2). The total content of PLFAs was 2-3 319 times lower for the pure beech stands in comparison with the other broadleaf forest types (e.g. 320 hornbeam, lime, maple or ash) (Scheibe et al. 2015). This is a consequence of low $\mathrm{pH}$ and presence 321 of specific compounds in root exudates composition (Scheibe et al. 2015). The increase of PLFAs content under the two species mixtures with beech is explained by presence of the pioneer species alder and birch, which are usually used to improve soil quality before planting the secondary forest species such as beech (Frouz et al. 2015). Moreover, alder is an N-fixer, which can provide additional $\mathrm{N}$ for microorganisms in soil under two species mixtures forests (Frouz et al. 2015; Walker and Chapin 1986; Chapin et al. 1994). In contrast, mixtures containing both oak trees and 327 primary succession species did not stimulate an increase in microbial biomarkers content (Fig. 2). The same effect was found for the three species mixtures because partly opposite effects of the tree species (Fig. 2) compensating each other in mixtures. In conclusion, it appears that tree species identity has a stronger effect than amount of species on the content of total PLFAs in the afforested 331 soils.

\section{Afforestation effects on microbial community composition}

Afforestation increased the content of bacterial and fungal PLFAs, however, fungal biomarkers increased 2 times higher than those for bacterial. Afforestation usually promotes development of fungi (Yannikos et al. 2014; Macdonald et al. 2009; Carson et al. 2010) and induces 337 changes in fungal community composition (Carson et al. 2010). An increase in fungal biomarker 338 content after afforestation can be attributed to the both direct effects of the trees themselves and 339 indirect effects due to changes in the environment. Of the direct tree effects, fungal biomass is 340 stimulated by, i) a shift from easy decomposable crop residues to more recalcitrant leaf litter rich in 
polyphenol/tannin compounds (Rousk and Baath 2007; Yannikos et al. 2014), and ii) development

342 of plant species, which are strongly ectomycorrhizal such as birch, alder and oak (Baum et al. 343 2009). Of the indirect effects, i) termination of agricultural practice stimulates the development of 344 fungi due to less physical disruption of hyphal networks (Helgason et al. 2009; Strickland and 345 Rousk 2010), and ii) a decrease in soil pH suppresses bacterial growth and makes fungi more 346 competitive in terms of substrate utilization (Swift et al. 1979; Zeller et al. 2001).

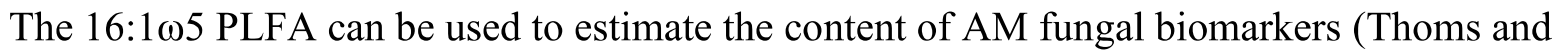
348 Gleixner 2013; Madan et al. 2002) although we acknowledge that this may also be present in G349 bacteria (Nichols et al. 1986). In contrast to fungal PLFAs, the content of the 16:165 PLFA 350 increased by 30 to $120 \%$ (for some cases) and even decreased (for beech and three species forest 351 mixtures) (Fig. 3). This either can reflect i) the shift in fungal community from arbuscular 352 mycorrhizal communities, inherent for agriculture and pasture soils, to ectomycorrhizal 353 communities which dominate under forests (Macdonald et al. 2009) or ii) the changes in portion of 354 microorganisms with rapid growth strategy in total microbial community (Priha et al. 1999). Bacterial biomass was less affected by a shift away from an agricultural management regime 356 than fungi. This is agreement with Klein et al. (1995) who suggested that abandonment of 357 agricultural land and subsequent afforestation should not strongly affect that part of soil microbial 358 community. However, based on our PLFA analysis, the amount of bacterial biomarkers increased 359 with afforestation, which agrees with other findings (van der Wal et al. 2006). Also, there was a 360 similar increase of $\mathrm{G}+$ and G- biomarkers in the most forest plots (except three species mixtures 361 with beech and birch+oak) (Fig. 3), which is in one line with data on similar portions of G+ and G362 PLFAs found for the old growing oak and beech forests (Hackl et al. 2005). Increases in the G363 bacterial biomarkers may be connected with the increasing the volume of rhizosphere in forest soils 364 compare to agricultural (Thoms and Gleixner 2013), whereas increases in $\mathrm{G}+$ biomarkers may 365 occur due to intensive decomposition of $\mathrm{C}$ from previous land use. 
The average increase of PLFAs associated with actinomycetes was $50-150 \%$ and was

detected only for pure birch stand and two species mixtures (the highest with presence of alder),

whereas for other plots they decreased or were similar to the agricultural soil (Fig. 3). Decrease in

actinomycete biomarker content is related to the increasing the content of fungal biomass which is

known to suppress the development of the actinomycete community (Lewandowski et al. 2015;

Boer et al. 2005). From this study we conclude that changes in the content of microbial biomarkers following afforestation were greater compared to the major soil quality indicators. Afforestation affected the development of fungal biomass to a greater degree than bacterial biomass. Shifts in the content of particular biomarkers was found in all forest plots, suggesting that the amount of tree species is not the main factor controlling soil microbial community changes. At the same time, the relative increase in biomarker content was related to tree identity, revealing that individual tree species promoted greater change relative to mixed-species forest. Further, no additive effects of individual tree species were found.

\section{Forest composition effects on soil microbial communities}

According to PCA analysis forest soil plots were different from the agricultural plot mainly

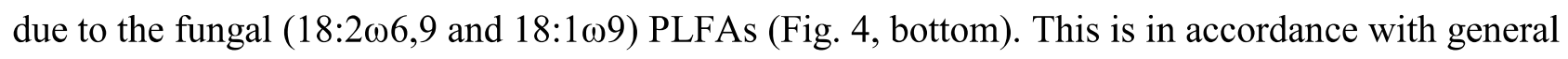
increase of fungal biomarkers in forest soils (Fig. 3). Decrease of soil acidity contributed the most to separation of forest and agricultural plots, which is frequently reported for forest soils (Scheibe et al. 2015; van der Wal et al. 2006).

According to the PCA, one- and three species mixture forests were more similar in PLFA composition than two species mixtures (Fig. 4, top). The most relevant groups in differentiation of two species mixtures from monoculture and three species forests were 10Me16:0 and 10Me18:0, common for actinomycetes (Zelles 1997) and branched PLFAs i16:0 and a16:0, common for G+ bacteria (Zelles 1997) (Fig. 4, bottom). The late successional tree species together with two early 
communities similar to monoculture forests (Fig. 4, top). The most relevant PLFAs for separation of

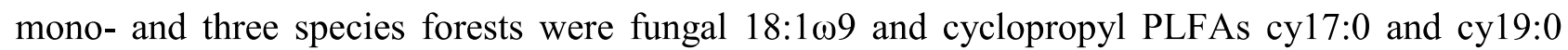
(Fig. 4, bottom).

Thus, the specific microbial community types were formed in the soils under the tested forest types already 10 years after planting. Similar microbial communities developed in soils under mono- and three species forest mixtures point on the absence of additive effect if two early primary successional species grow together. In contrast, simultaneous development of one early primary and one late successional tree species forms soil microbial communities with completely different composition.

\section{Conclusions}

Afforestation by one-, two- and three species mixtures with contrasting sets of functional traits, revealed the effects of trees identity and forest tree community composition on changes in soil chemistry and the structure of microbial communities. In support of our first hypothesis, total PLFA content increased more than $100 \%$ in forest soils compared to the agricultural, whereas changes in soil chemical properties ( $\mathrm{C}$ and $\mathrm{N}$ contents, dissolved $\mathrm{N}$ forms) were altered to a lesser degree. Total PLFA contents for monocultural forests (except beech) were higher than for the mixtures, indicating that tree species identity has a stronger effect than number of species on the content of microbial biomarkers and no additive effects of increasing species number were observed.

The content of fungal biomarkers was changed by afforestation to much greater extent than for bacteria in agreement with our second hypothesis. Increase of particular biomarkers for all forests was independent of tree species amount, reflecting absence of additive effect of forest mixtures on the content of specific microbial biomarkers.

The PCA analysis revealed that two species mixtures were separated from one- and three species forests due to a higher abundance of actinomycetes and $\mathrm{G}+$ bacterial biomarkers. In 
418 contrast, microbial community composition for single species forests were similar to the three 419 species mixtures, and could only be separated along PC2 due to a high abundance of G- bacterial 420 biomarkers. Thus, development of forest monocultures, even formed by species having different 421 functional traits promotes formation of similar microbial communities. In contrast, the simultaneous 422 presence of early primary and late successional tree species stimulates the development of different 423 community compositions, but this effect is dampened in mixtures of two early primary and late 424 successional species.

\section{Acknowledgements}

This study was supported by a grant from the Erasmus Mundus Joint Doctoral Programme "Forest and Nature for Society" (FONASO) awarded to A. Gunina. BangorDIVERSE was supported by the Sêr Cymru National Research Network for Low Carbon Energy and Environment. 


\section{References}

458

459

460

461

462

463

464

465

466

467

468

469

470

471

472

473

474

475

476

477

478

479

480

481

482

483

484

485

486

487

488

489

490

491

492

493

494

495

496

497

498

499

500

501

502

Ahmed IU, Smith AR, Jones DL, Godbold DL (2016) Tree species identity influences the vertical distribution of labile and recalcitrant carbon in a temperate deciduous forest soil. Special Section: Forests, Roots and Soil Carbon. Forest Ecology and Management 359:352-360. doi:10.1016/j.foreco.2015.07.018.

Apostel C, Dippold MA, Glaser B, Kuzyakov Y (2013) Biochemical pathways of amino acids in soil. Assessment by position-specific labeling and 13C-PLFA analysis. Soil Biology \& Biochemistry 67:31-40.

Baum C, Toljander YK, Eckhardt K-U, Weih M (2009) The significance of host-fungus combinations in ectomycorrhizal symbioses for the chemical quality of willow foliage. Plant and Soil 323:213-224. doi:10.1007/s11104-009-9928-x.

Berthrong ST, Jobbaagy EG, Jackson RB (2009) A global meta-analysis of soil exchangeable cations, $\mathrm{pH}$, carbon, and nitrogen with afforestation. Ecological Applications 19:2228-2241.

Boer WD, Folman LB, Summerbell RC, Boddy L (2005) Living in a fungal world: impact of fungi on soil bacterial niche development. FEMS Microbiology Reviews 29:795-811. doi:10.1016/j.femsre.2004.11.005.

Buckley DH, Schmidt TM (2003) Diversity and dynamics of microbial communities in soils from agroecosystems. Environmental Microbiology 5:441-452.

Carson JK, Gleeson DB, Clipson N, Murphy DV (2010) Afforestation alters community structure of soil fungi. Fungal Biology 114:580-584. doi:10.1016/j.funbio.2010.04.008.

Chapin FS, Walker LR, Fastie CL, Sharman LC (1994) Mechanisms of Primary Succession Following Deglaciation at Glacier Bay, Alaska. Ecological Monographs 64:149-175.

Cong J, Yang Y, Liu X, Lu H, Liu X, Zhou J, Li D, Yin H, Ding J, Zhang Y (2015) Analyses of soil microbial community compositions and functional genes reveal potential consequences of natural forest succession. Scientific reports 5:10007. doi:10.1038/srep10007.

DeLuca TH, Boisvenue C (2012) Boreal forest soil carbon: distribution,function and modelling. Forestry doi:10.1093/forestry/cps003.

Frostegard A, Tunlid A, Baath E (1991) Microbial biomass measured as total lipid phosphate in soils of different organic content. Journal of Microbiological Methods 14:151-163. doi:10.1016/0167-7012(91)90018-1.

Frouz J, Voborilová V., Janoušová I., Kadochová Š, Matejícek L (2015) Spontaneous establishment of late successional tree species Englishoak (Quercus robur) and European beech (Fagus sylvatica) at reclaimed alder plantation and unreclaimed post mining sites. Ecological Engineering 77:1-8.

Fu X, Yang F, Wang J, Di Y, Dai X, Zhang X, H W (2015) Understory vegetation leads to changes in soil acidity and in microbial communities 27 years after reforestation. Science of the Total Environment 502:280-286.

Glanville H, Rousk J, Golyshin P, Jones DL (2012) Mineralization of low molecular weight carbon substrates in soil solution under laboratory and field conditions. Soil Biology \& Biochemistry 48:88-95. doi:10.1016/j.soilbio.2012.01.015.

Grayston SJ, Vaughan D, Jones D (1997a) Rhizosphere carbon flow in trees, in comparison with annual plants. The importance of root exudation and its impact on microbial activity and nutrient availability. Applied Soil Ecology 5:29-56. doi:10.1016/s0929-1393(96)00126-6.

Grayston SJ, Vaughan D, Jones D (1997b) Rhizosphere carbon flow in trees, in comparison with annual plants. The importance of root exudation and its impact on microbial activity and nutrient availability. Applied Soil Ecology 5:29-56. doi:10.1016/s0929-1393(96)00126-6. 
Gunina A, Dippold M, Glaser B, Kuzyakov Y (2014) Fate of low molecular weight organic substances in an arable soil. From microbial uptake to utilisation and stabilisation. Soil Biology \& Biochemistry 77:304-313.

Hackl E, Pfeffer M, Donat C, Bachmann G, Zechmeister-Boltenstern S (2005) Composition of the microbial communities in the mineral soil under different types of natural forest. Soil Biology \& Biochemistry 37:661-671.

Helgason BL, Walley FL, Germida JJ (2009) Fungal and bacterial abundance inlong-term no-till and intensive-till soils of the Northern Great Plains. Soil Sci. Soc. Am. J. 73:120-127.

Jangid K, Williams MA, Franzluebbers AJ, Schmidt TM, Coleman DC, Whitman WB (2011) Landuse history has a stronger impact on soil microbial communitycomposition than aboveground vegetation and soil properties. Soil Biology \& Biochemistry xxx:1-10.

Jobbágy EG, Jackson RB (2003) Patterns and mechanisms of soil acidification in the conversion of grasslands to forests. Biogeochemistry 64:205-229. doi:10.1023/A:1024985629259.

Kalinina O, Krause SE, Goryachkin SV, Karavaeva NA, Lyuri DI, Giani L (2011) Self restoration of post-agrogenic chernozems of Russia: soil development, carbon stocks, and dynamics of carbon pools. Geoderma 162:196-206.

Klein DA, McLendon T, Paschke MW, Redente EE (1995) Saprophytic fungal-bacterial biomass variations in successional communities of a semi-arid steppe ecosystem. Biology and Fertility of Soils 19:253-256.

Kurganova I, Lopes De Gerenyu V, Kuzyakov Y (2015) Large-scale carbon sequestration in postagrogenic ecosystems in Russia and Kazakhstan. Catena 133:461-466. doi:10.1016/j.catena.2015.06.002.

Laganière J, Paré D, Bergeron Y, Chen H (2012) The effect of boreal forest composition on soil respiration is mediated throughvariations in soil temperature and $\mathrm{C}$ quality. Soil Biology \& Biochemistry 53:18-27.

Leckie SE (2005) Methods of microbial community profiling and their application to forest soils. Forest Ecology and Management 220:88-106.

Lewandowski TE, Forrester JA, Mladenoff DJ, Stoffel JL, Gower ST, D’Amato AW, Balser TC (2015) Soil microbial community response and recovery following group selection harvest. Temporal patterns from an experimental harvest in a US northern hardwood forest. Forest Ecology and Management 340:82-94.

Li H, Ye D, Wang X, Settles ML, Wang J, Hao Z, Zhou L, Dong P, Jiang Y, Ma Z Soil bacterial communities of different natural forest types in Northeast China. Plant and Soil 383:203-216. doi:10.1007/s11104-014-2165-y.

Li M, Zhou X, ZHANG Q, Cheng X (2014) Consequences of afforestation for soil nitrogen dynamics in central China. Agriculture, Ecosystems and Environment 183:40-46.

Macdonald CA, Thomas N, Robinson L, Tate KR, Ross DJ, Dando J, Singh BK (2009) Physiological, biochemical and molecular responses of the soil microbial community after afforestation of pastures withPinus radiata. Soil Biology \& Biochemistry 41:1642-1651.

Madan R, Pankhurst C, Hawke B, Smith S (2002) Use of fatty acids for identification of AM fungi and estimation of the biomass of AM spores in soil. Soil Biology \& Biochemistry 34:125-128. doi:10.1016/s0038-0717(01)00151-1.

Mann L, Tolbert V (2000) Soil sustainability in renewable biomass plantings. Ambio 29:492-498.

Mulvaney RL (1996) Methods of Soil Analysis. Part 3 - Chemical Methods. Nitrogen - Inorganic Forms. Soil Science Society of America, Inc., Wisconsin, USA. 
Nazaries L, Tottey W, Robinson L, Khachane A, Al-Soudd WA, Sørensen S, Singh BK (2015) Shifts in the microbial community structure explain the response of soil respiration to land-use change but not to climate warming. Soil Biology \& Biochemistry 89:123-134.

Nichols P, Stulp BK, Jones JG, White DC (1986) Comparison of fatty acid contentand DNA homology of the filamentous gliding bacteria Vitreoscilla, Flexibacter,Filibacter. Archives of Microbiology 146:1-6.

Paul KI, Polglase PJ, Nyakuengama JG, Khanna PK (2002) Change in soil carbon following afforestation. Forest Ecology and Management 168:241-257. doi:10.1016/S03781127(01)00740-X.

Priha O, Grayston SJ, Pennanen T, Smolander A (1999) Microbial activities related to C and N cycling and microbial community structure in the rhizospheres ofPinus sylvestris, Picea abiesandBetula pendulaseedlings in an organic and mineral soil. Fems Microbiology Ecology 30:187-199.

Ritter E, Vesterdal L, Gundersen P (2003) Changes in soil properties after afforestation of former intensively managed soils with oak and Norway spruce. Plant and Soil 249:319-330.

Rousk J, Baath E (2007) Fungal biomass production and turnover in soil estimated using the acetate-in-ergosterol technique. Soil Biology \& Biochemistry 39:2173-2177. doi:10.1016/j.soilbio.2007.03.023.

Scheibe A, Steffens C, Seven J, Jacob A, Hertel D, Leuschner C, Gleixner G (2015) Effects of tree identity dominate over tree diversity on the soil microbial community structure. Soil Biology \& Biochemistry 81:219-227.

Smith A., Lukac M., Hood R., Healey J.R., Miglietta F., Godbold D.L. (2013) Elevated CO2 enrichment induces a differential biomass response in a mixed species temperate forest plantation. New Phytologist 198:156-168.

Strickland MS, Rousk J (2010) Considering fungal. bacterial dominance in soils - Methods, controls, and ecosystem implications. Soil Biology \& Biochemistry 42:1385-1395. doi:10.1016/j.soilbio.2010.05.007.

Swift MJ, Heal OW, Anderson JM (1979) Decomposition in Terrestrial Ecosystems. Oxford.

Thoms C, Gleixner G (2013) Seasonal differences in tree species' influence on soil microbial communities. Soil Biology \& Biochemistry 66:239-248.

Trap J, Hättenschwiler S, Gattin I, Aubert M (2013) Forest ageing: An unexpected driver of beech leaf litter quality variability in European forests with strong consequences on soil processes. Forest Ecology and Management 302:338-345.

Uri V, Lohmus K, Tullus H (2003) Annual net nitrogen mineralization in a grey alder (Alnus incana(L.) moench) plantation on abandoned agricultural land. Forest Ecology and Management 184:167-176.

van der Wal A, van Veen JA, Smant W, Boschker H, Bloem J, Kardol P, van der Putten WH, Boer $\mathrm{W}$ de (2006) Fungal biomass development in a chronosequence of land abandonment. Soil Biology \& Biochemistry 38:51-60.

Walker LR, Chapin FS (1986) Physiological controls over seedling growth in primary succession on an Alaskan flood plain. Ecology 67:1508-1523.

Yannikos N, Leinweber P, Helgason BL, Baum C, Walley FL, van Rees K (2014) Impact of Populus trees on the composition of organic matter and the soil microbial community in Orthic Gray Luvisols in Saskatchewan (Canada). Soil Biology \& Biochemistry 70:5-11. 
600

601

602

603

604

605

606

607

608

609

610

Zeller V, Bardgett RD, Tappeiner U (2001) Site and management effects on soil microbial properties of subalpine meadows: a study of land abandonment along a north-south gradient in the European Alps. Soil Biology and Biochemistry 33:639-649. doi:10.1016/S00380717(00)00208-X.

Zelles L (1997) Phospholipid fatty acid profiles in selected members of soil microbial communities. Chemosphere 35:275-294. doi:10.1016/s0045-6535(97)00155-0.

\section{Table captions}

Table 1. Properties of the forest tree species.

Table 2. Ratios of saturated/monounsaturated (sat/mono) PLFAs (calculated as

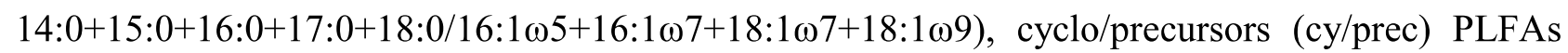

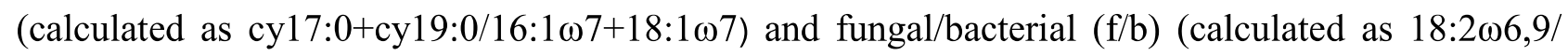
i15:0+a15:0+15:0+i16:0+16:1 $\omega 7+\mathrm{i} 17: 0+\mathrm{a} 17: 0+\operatorname{cy} 17: 0+\mathrm{cy} 19: 0+18: 1 \omega 7)$ for soils under the different forest treatments and the agricultural plots. Data present mean \pm st. error, $n=4$. Forest treatments: Al (alder), Bi (birch), Be (beech), Oa (oak), ABe (alder+beech), AOa (alder+oak), BiBe (birch+beech), BiOa (birch+oak), ABiBe (alder+birch+beech), ABiOa (alder+birch+oak). Agr agricultural plot.

\section{Figure captions}

Fig 1. Changes of soil chemical properties in the various forest treatments relative to the agricultural soil (Agr). Data present mean \pm st. error, $n=4$. Letters above error bars present significant differences $(p<0.05)$ between the treatments for the each parameter separately. Red letters are for $\mathrm{C} / \mathrm{N}$ ratios, blue letter are for $\mathrm{C}$ and green are for $\mathrm{N}$. In case of $\mathrm{pH}$ no statistical differences between the forests were found, only differences between forest and agricultural soil was found. Forest treatments: Al 
(alder), Bi (birch), Be (beech), Oa (oak), ABe (alder+beech), $\mathrm{AOa}$ (alder+oak), BiBe (birch+beech), $\mathrm{BiOa}$ (birch+oak), $\mathrm{ABiBe}($ alder+birch+beech), $\mathrm{ABiOa}$ (alder+birch+oak).

626

Fig 2. Content of total PLFAs (nmol g ${ }^{-1}$ soil) in the different forest treatments and the agricultural soil. Data present mean \pm st error, $n=4$. Letters above error bars present significant differences $(p<$ 0.05 ) between the treatments. Forest treatments: $\mathrm{Al}$ (alder), Bi (birch), Be (beech), Oa (oak), ABe (alder+beech), $\quad \mathrm{AOa} \quad$ (alder+oak), $\quad \mathrm{BiBe} \quad($ birch+beech), $\quad \mathrm{BiOa} \quad$ (birch+oak), $\mathrm{ABiBe}$ (alder+birch+beech), ABiOa (alder+birch+oak).

Fig 3. Changes in the content ( $\mathrm{n} \mathrm{mol} \mathrm{g}{ }^{-1}$ soil) of specific microbial indicators PLFAs in the different forest treatments relative to the agricultural soils, presented as portion of changes. Data present mean \pm st. error, $n=4$. Letters above error bars present significant differences $(p<0.05)$ between the plots for the each group separately. Top figure - red letters are for G- bacterial PLFAs, black letters are for G+ PLFAs; bottom figure - violett letters are for fungal PLFAs, black are for 16:1w5 PLFA and green are for actinomycetes PLFAs. Forest treatments: Al (alder), Bi (birch), Be (beech), Oa (oak), $\mathrm{ABe}$ (alder+beech), $\mathrm{AOa}$ (alder+oak), BiBe (birch+beech), BiOa (birch+oak), ABiBe (alder+birch+beech), ABiOa (alder+birch+oak).

Fig. 4. Score plot of PCA presenting the separation of mono- and mixture species forests along the principal component PC1 and PC2 (top) and loading values for the PLFAs (bottom). Forest treatments: Al (alder), Bi (birch), Be (beech), Oa (oak), ABe (alder+beech), AOa (alder+oak), BiBe (birch+beech), BiOa (birch+oak), ABiBe (alder+birch+beech), ABiOa (alder+birch+oak). Colors for the loading values of PLFAs indicate the following: red - Gram-negative bacterial, yellow universal microbial biomarker, green - actinomycetes, blue - Gram-positive bacteria, violet - fungi. 


\section{Table 1}

Table 1. Properties of the forest tree species.

\begin{tabular}{lcccc}
\hline Plant species & English oak & European beech & Silver birch & European alder \\
\hline $\begin{array}{l}\text { Succession stage } \\
\begin{array}{l}\text { Mycorrhization } \\
\text { degree }\end{array}\end{array}$ & Late & Late & Early primary & Early primary \\
$\begin{array}{l}\text { Type of } \\
\text { mycorrhization }\end{array}$ & Ecto & High & High & Weak \\
$\begin{array}{l}\text { C/N ratio of plant } \\
\text { litter }\end{array}$ & 38.73 & Ecto & Ecto & $\begin{array}{c}\text { Ecto- and } \\
\text { arbuscular }\end{array}$ \\
\hline
\end{tabular}


Table. 2

Table 2. Ratios of saturated/monounsaturated (sat/mono) PLFAs (calculated as 14:0+15:0+16:0+17:0+18:0/16:1 $\omega 5+16: 1 \omega 7+18: 1 \omega 7+18: 1 \omega 9)$, cyclo/precursors (cy/prec) PLFAs

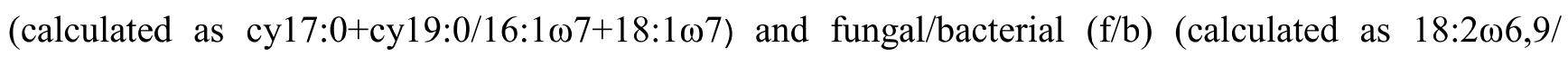
$\mathrm{i} 15: 0+\mathrm{a} 15: 0+15: 0+\mathrm{i} 16: 0+16: 1 \omega 7+\mathrm{i} 17: 0+\mathrm{a} 17: 0+\mathrm{cy} 17: 0+\mathrm{cy} 19: 0+18: 1 \omega 7)$ for soils under the different forest treatments and the grassland control plots. Data present mean \pm st. error, $n=4$. Forest treatments: Al (alder), Bi (birch), Be (beech), Oa (oak), ABe (alder+beech), AOa (alder+oak), BiBe (birch+beech), BiOa (birch+oak), ABiBe (alder+birch+beech), ABiOa (alder+birch+oak); Agr agricultural plot.

\begin{tabular}{|c|c|c|c|c|c|c|c|c|c|c|c|}
\hline Forest & A & $\mathrm{Bi}$ & $\mathrm{Be}$ & $\mathrm{Oa}$ & $\mathrm{ABe}$ & $\mathrm{AOa}$ & $\mathrm{BiBe}$ & $\mathrm{BiOa}$ & $\mathrm{ABiBe}$ & $\mathrm{ABiOa}$ & Agr \\
\hline sat/mono & $0.65 \pm 0.01$ & $0.62 \pm 0.01$ & $0.69 \pm 0.04$ & $0.68 \pm 0.05$ & $0.7 \pm 0.03$ & $0.78 \pm 0.02$ & $0.63 \pm 0.03$ & $0.72 \pm 0.03$ & $0.58 \pm 0.02$ & $0.63 \pm 0.03$ & $0.69 \pm 0.01$ \\
\hline cy/prec & $0.49 \pm 0.02$ & $0.55 \pm 0.02$ & $0.59 \pm 0.03$ & $0.53 \pm 0.04$ & $0.5 \pm 0.05$ & $0.58 \pm 0.03$ & $0.51 \pm 0.03$ & $0.47 \pm 0.02$ & $0.55 \pm 0.03$ & $0.55 \pm 0.02$ & $0.41 \pm 0.01$ \\
\hline$f / b$ & $0.043 \pm 0.006$ & $0.063 \pm 0.004$ & $0.05 \pm 0.004$ & $0.054 \pm 0.007$ & $0.069 \pm$ & $0.062 \pm 0.003$ & $0.076 \pm 0.013$ & $0.074 \pm 0.004$ & $0.064 \pm 0.01$ & $0.055 \pm 0.009$ & $0.033 \pm 0.001$ \\
\hline
\end{tabular}


Fig. 1
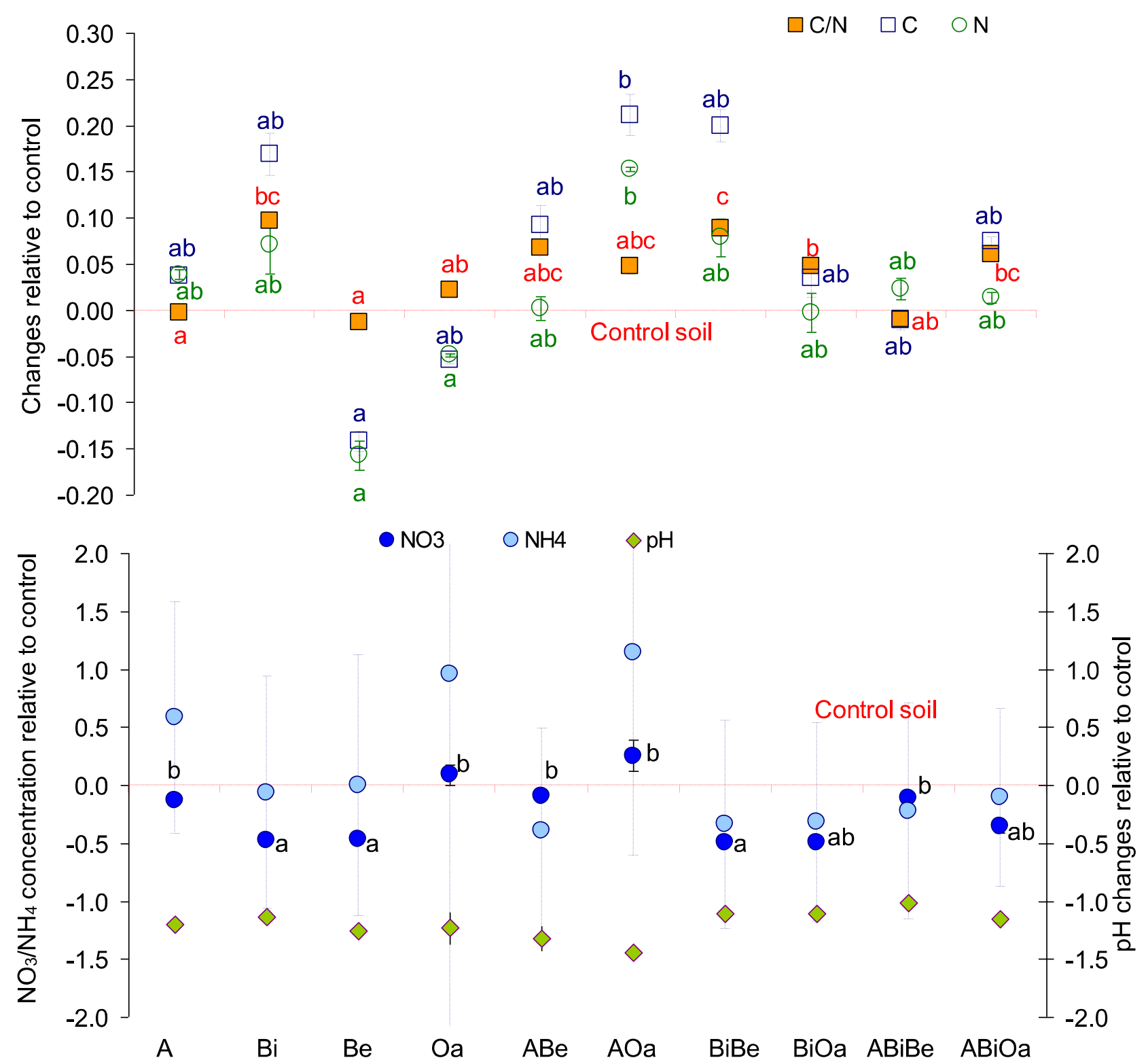
Fig. 2

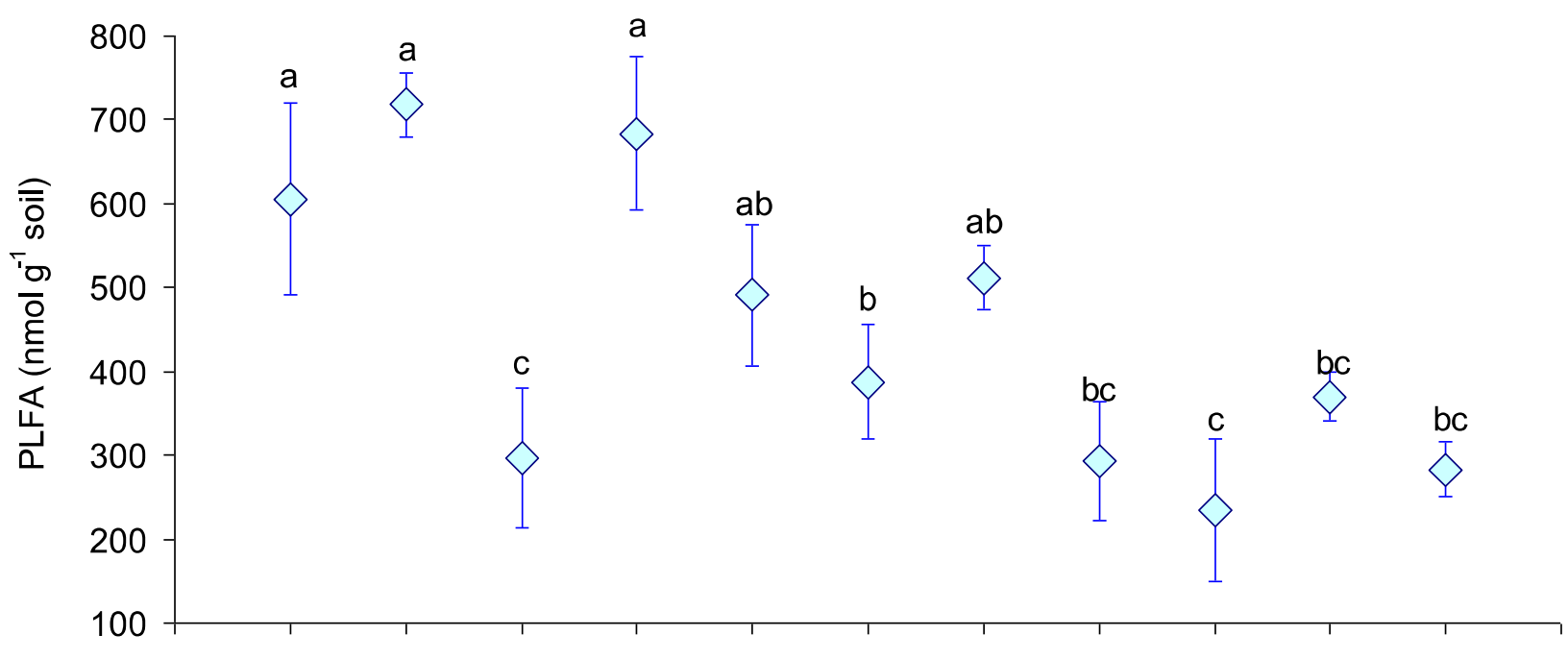

A $\mathrm{Bi}$ Be $\mathrm{Oa}$ Abe $\mathrm{AOa}$ BiBe $\mathrm{BiOa}$ ABiBe ABiOa Agr 
Fig. 3

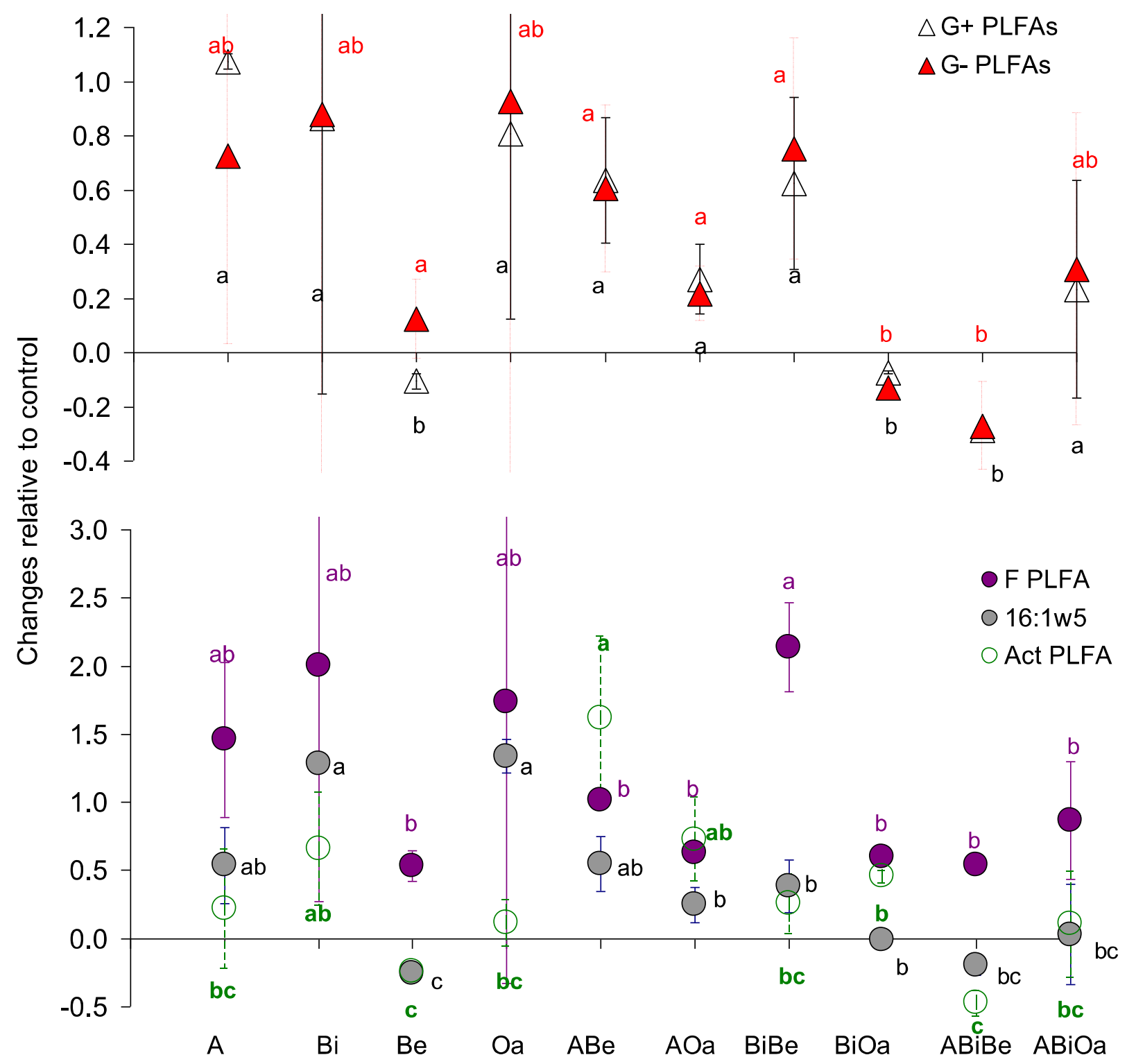


Fig. 4
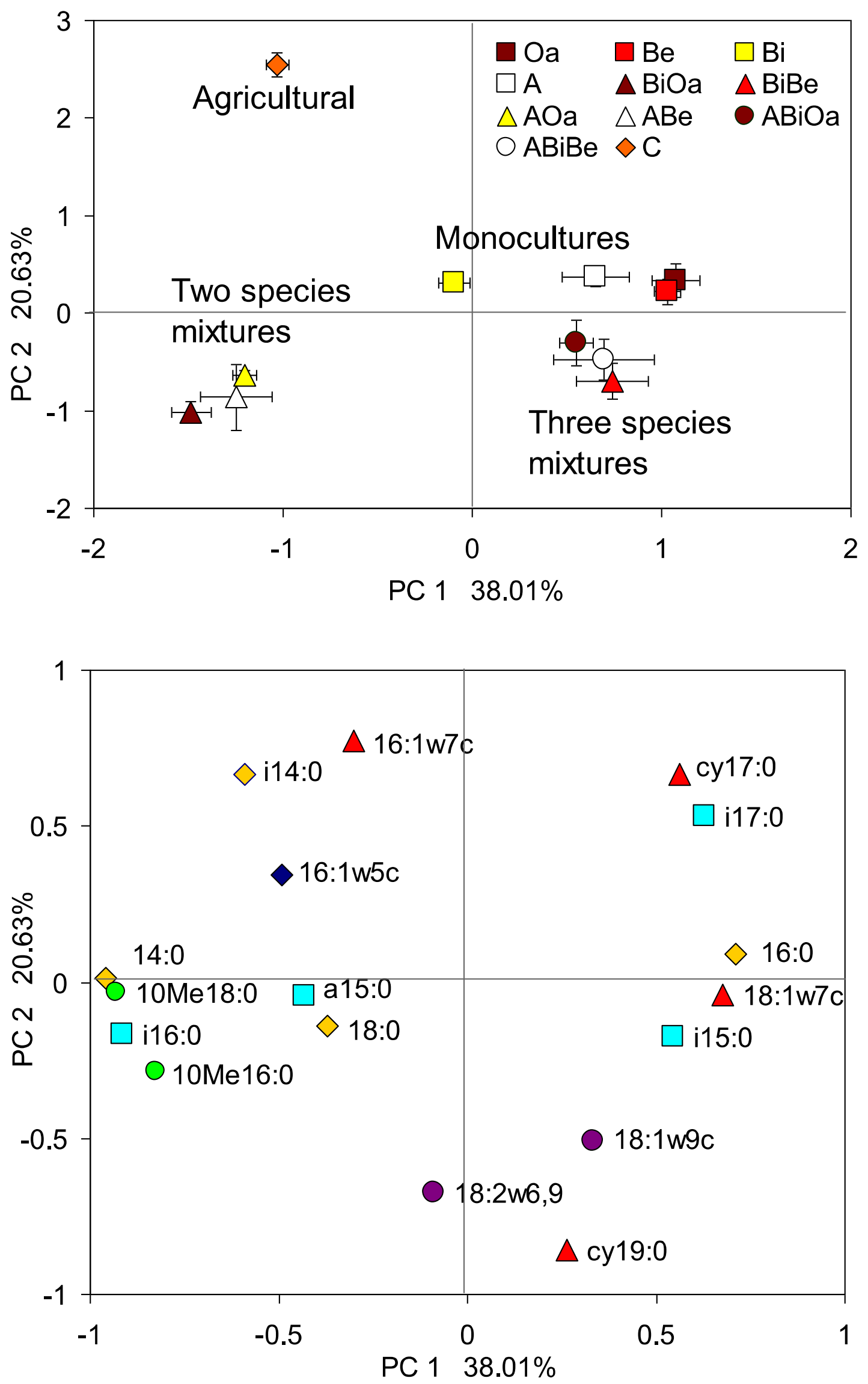
Click here to access/download

Electronic supplementary material supplementary tables.doc 